\title{
Indigenous Peoples Involment At The Environmental Impact Assessment (EIA) Process in Tabi Mamta Area Of Papua Province
}

\author{
Ferdinand Saras Dhiksawan ${ }^{1 *}$, Sudharto P. Hadi $^{2}$, Adji Samekto $^{3}$, Dwi P. Sasongko ${ }^{4}$ \\ ${ }^{1}$ Doctoral Program of Environmental Science, School of Postgraduate Studies, Universitas Diponegoro \\ ${ }^{2}$ Doctoral Program of Environmental Science, School of Postgraduate Studies, Universitas Diponegoro \\ ${ }^{3}$ Law Faculty, Universitas Diponegoro \\ ${ }^{4}$ science and Mathematic Faculty, Universitas Diponegoro
}

\begin{abstract}
The purpose of this study is to find a picture of the involvement of Indigenous Peoples of Tabi Mamta in the process of environmental impact assessment (EIA) in Tabi Mamta customary territory. The method and type of research used is non-ethnographic qualitative research with data collection techniques using limited observation techniques. Data and information in the field will be analyzed using constructivism paradigm. The paradigm of constructivism is based on an interpretive understanding called hermeneutics (hermeneuien) in the sense of interpreting, giving understanding, translating data and information obtained in the research location as a result of social reality. The results of this study indicate that the customary community of Tabi Mamta is a unit of customary community that still has territorial customary territory, has a customary leadership structure, still visible relationship of kinship, cultural values as well as customary norms and sanctions, and has environmental wisdom in maintaining existence Natural resources. In the socio-cultural system of customary communities there are components such as customary stratification, permissiveness, communication, reciprocity, past history, cultural values, customary norms and sanctions, religious and customary leadership. Components in the socio-cultural system of indigenous and tribal peoples play a role in the EIA process in the Tabi Mamta customary area especially in the environmental feasibility decision making process. The components of custom stratification, cultural values and customary norms play a role in the EIA process. In customary stratification there is uncustomary structure in the ondoafi, Iram and Tribal Leadership. Components in a sociual cultural system is a unity resulting from interaction between individuals and groups to prevent environmental damage and disturbance of natural resources. Natural resources are considered as ancestral symbols passed down by ancestors from generation to generation
\end{abstract}

\section{Introduction}

Papua is located in the eastern part of Indonesia. It has two provincial administrative areas, namely West Papua Province and Papua Province, where there are 7 (seven) customary areas, namely Tabi Mamta, La-Pago, HaAnim, Mi- Pago, Saireri, Bomberai, and Domberai. In the Amdal process, indigenous and tribal peoples feel that there is injustice, inequality, disagreement based on the existence of customary values and norms within the customary law community's living order. The purpose of this study is to find a picture of the involvement of Indigenous Peoples of Tabi Mamta in the process of analyzing environmental impacts in the Tabi Mamta customary territory.

The type of research used is non-ethnographic qualitative research with data collection techniques using limited observation techniques. Data and information in the field will be analyzed using constructivism paradigm.
The paradigm of constructivism is based on an interpretive understanding called hermeneutics (hermeneuien) in the sense of interpreting, giving understanding, translating data and information obtained in the research location as a result of social reality. The results describe the components in the social cultural system of customary and tribal peoples in the Environmental Impact Analysis process in Tabi Mamta Customary Area. Furthermore, in this research, the existence of Tabi Mamta customary Community is a community which still has territorial of customary territory, has a clear and respected leadership structure (Ondoafi, Iram, and Chief of Tribe), the relationship of kinship, cultural values and customary norms and sanctions, and have environmental wisdom in maintaining the existence of Natural Resources.

The values and norms in the life of indigenous peoples, as well as the existence of natural resources as property rights of Indigenous People of ancestral lands

Corresponding author: dhiksawan@yahoo.co.id 
are recognized and protected by the Regional Government through legislation.

\section{Material and Research Methods}

The type of research used is non-ethnographic qualitative research with data collection techniques using limited observation techniques. Data and information in the field were obtained through in-depth interviews using unstructured structured question materials (using recording instruments) on key figures (key informants). Determination of key figures as a source of data and information obtained through snowball technique (snowball sampling).

Further data and information obtained will be analyzed using constructivism paradigm. The paradigm of constructivism is based on an interpretive understanding called hermeneutics (hermeneuien) in the sense of interpreting, giving understanding, translating data and information obtained in the research location as a result of social reality

\section{Research Result}

Tabi Mamta customary territory is located in the northern part of Jayapura (in the east by Papua New Guinea) up to Mamberamo (western) and South bordering Jayawijaya Mountains. Administratively, the territory of Tabi Mamta Indigenous Peoples covers Keerom Regency, Jayapura City, Jayapura Regency, Sarmi Regency and Mamberamo Raya Regency.

The Tabi Mamta People is called TABI MAMTA because it comes from the Sunrise (TABI) which then resides in the Mamberamo River Basin and the Tami River Basin (MAMTA). The history of the journey of the Tabi Mamta People begins with the existence of a Sun and Moon god who bears the Sun and Moon. The God of the Sun and the Moon began the journey from where the sun began. Furthermore, the first stopover of the Sun and Moon gods from the east is called Tabatji village (first village). After a night of exhaustion, then the journey continues back towards the West. Arriving in one place, the Sun and Moon gods no longer continue their journey. Pikulan in the form of a Sun and the Moon then placed somewhere that causes the occurrence of a large hole.

The place is now called Bhuyakha (Water Place) or called Lake Sentani. It is from this place that later generations to the genaration develop and inhabit the Mamberamo River Basin and the Tami River Basin. For that reason, the Tabi Mamta Indigenous Peoplehighly appreciates their leaders because the people still consider that their leader is the incarnation of the sun god and the moon. Their leader is called Ondofolo or ondoafi, and for certain customary territories is called Iram. The view of Indigenous Peoplewhich still holds the leadership of Ondofolo said that Tabi Mamta People comes from Tabi meaning sunrise, up to Mamberamo River Basin Region and Tami River Basin. While the view of the Indigenous
Peopleof Iram argues that the origin of the Tabi Mamta Customary Law spread from the upper Mamberamo River across the mountains in the Mamberamo region to the Sarmi region and spread to Fak Fak area (found the same clan name that is the "Wou" clan) which is administratively Is in West Papua Province. According to the story of the ancestors this incident stems from the separation of brother and sister due to tribal wars that resulted in scattering toward the West

\section{Indigenous Peoples Leadership System Keondoafian}

The system of keondoafian is a system of leadership of the Tabi Mamta Customary Law Community, led by a hereditary patent (patrinial) who has birthright, is appointed and respected in indigenous peoples. Indigenous PeopleTabi Mamta ondofolo leadership considers that ondofolo is the incarnation of the sun and the moon god. The territory of the system of keondoafian is in the Sentani valley, the Grime valley to the north coast. Leaders in the Sentani valley and Grime valley are called ondofolo, while on the coast is called ondoafi. The word Ondoafi or Ondofolo comes from the language of Tepera namely Ondewafi which means Head of Customary Country or "Take care of the People", "Master who care, give life for the people".

The language of Tobaji calls Harsori, the Nimboran language of Iram or Dekening, the language of Kemtuk and Gresi mentioning Duguea and Dugeno, Jouwawary Language mentioning Matawun Pan or Marar Matawun, Nachaiba Language (Big and Small Ormu) called Tubwe and Moi Language mentioning Done word which means taking care of goods Pet. In the customary region Tabi Mamta is familiar with custom symbols. Customary symbols are highly respected, respected and have a high religious value. These custom symbols are communal lands, forest resources, and other natural resources. The symbols of customary have been traditionally adhered from the ancestors of the Tabi Mamta Customary Law Community. Indigenous symbols have always been under traditional rule. The highest customary authority governing custom symbols is in the hands of Ondofolo or Ondoafi. The customary structure of the cynosure system begins with a leader called ondofolo. Ondofolo in his leadership was assisted by the clans awarded Abhu Affa who was assigned as a substitute ondofolo when ondofolo was absent at an event, as well as the title of Abhu Akho who served as an intermediary or spokesman ondofolo, and Koselo (Ondofolo Yo) Stairs inside Yo (kampung). The structure under Koselo (ondofolo Yo) is a clan or Akhona, which is authorized to keep the customary treasures, and then the lowest structure is the people or the customary community called Akha Beakhe. The following figure shows the traditional structure of keondofoloan system. 


\section{Indigenous Peoples Leadership System Iram}

The Tabi Mamta Indigenous People which has the leadership pattern of the Iram system is in the Grime valley customary territory. According to the beliefs and beliefs of Indigenous Nambloung people that 3 (three) traditional leaders are symbols of the Sun. The customary leader or Iram is assisted by Takai who serves as uncustomary adviser or judge, as well as Duneskingwou who is a customary spokesman or daily executive. Iram's duties within the customary village are to protect the people from all threats and to promote the welfare of the people. Meanwhile, when out of the village customary Iram's duty is to establish relationships with Iram who was in another village. In traditional talks the spokesperson or daily executive (Duneskingwou) can not express his opinions before the advisor (Takai) expresses his opinion in the form of advice to Iram. So the decision issued by Iram as the supreme leader is considered to be the highest decision and is of a scral nature, and can not be violated. If the decision is violated then there will be custom sanctions that are believed to bring disaster to those who violate it.

In carrying out his duties then Iram assisted Duneskingwou as spokesperson or daily executive and Neskingwouw as head of general government. The Public Administration Board is divided into 4 (four) sections namely Yrung Neskingwoow as head of general government as well as Indigenous Council, Iram Tang as head of general government in charge of external affairs and in indigenous kampong, Takay Tang Neskingwoow as head of the affairs of the judiciary and community protector, And Takay Tang Sa Neskingwoow as head of general affairs in the field of customary justice. The meaning of Tang is clan (Clan) or clan that has line line of descentIram, Takay or Duneskingwoow.In addition there is also Undo Hamong You Hlu / Hamung bu lelou who served as a financial supervisor or Examination Agency treasures treasures and customary finance. While Undo Hamong $\mathrm{Bu} \mathrm{Hlu}$ as financial executor or Head of Kampung Finance Agency duty to receive, store, maintain and issue treasures customary treasures or money (dwei). In the leadership structure of Iram there are legal advisors called Hlu Waji or Ki Waji, as well as Wue Leng's duties as a messenger, and Flomewu Hlu as Commander of War.

\section{Indigenous Peoples of Collective Leadership System}

This pattern is located in the northern coastal area of Jayapura Regency, especially in Ambora, Tablanusu, Yepase, Dormena, Ormu, Tarvi and some areas of Keerom up to the border area of Papua New Guinea State (PNG). In addition, collective leadership patterns were also found in the villages of Meikari, Skori, Demetim, Sabeyab Kecil, Mamda and Aimbe. The Customary Law Society This Collective Leadership was formed due to the acculturation of culture, due to mixed marriage among tribes, and the inclusion of other tribes outside the majority tribe forming customary village. For example the occurrence of cultural mixing that can be seen from the names of the clan. For example the occurrence of cultural mixing that can be seen from the names of the clan. Like the clan name "Pangkatana" in custom area of doyo, which is a mixing culture Sentani and Genyem. Then clan "Marweri" which is a mix between Sentani culture, especially in Sentani lake area with Genyem. Similarly the "Wasangge" clan in the Kanda Boroway region is a mixture of Kemtuk culture with Genyem.

There is also a cultural mix between cultures of indigenous and tribal peoples who live in villages west of Lake Sentani with customary law communities residing in the Ormu region to the west of the Dormena region, Waib to the Kaptiaw region.Another example in the Tarvi region is the Subu tribe of Ronggowai tribe in Sarmi. So if there are customary events ondoafi will come to the Sarmi region to follow the traditional ceremony, which should follow the traditional ceremony in the region Tarond keondoafian. Tarvi region actually entered the administrative area of Sarmi Regency, while muaib entered the administrative area of Jayapura Regency.

The process of territorial capability begins with a system of exchange of natural resources (burter). Beginning with indigenous peoples of Genyem (Jayapura District), they have their fields swapped for the marine products brought by the Tarvi indigenous people. Then because it has been for a long time then the Genyem people build settlements in the coastal area of the Tarvi. The place is now called the village of Muaib.

Thus Tarvi and Muaib have different languages than other villages in the territory of Tarvi's terondoafian. The pattern of collective leadership is usually directed to the odowapi or the head of the Tribe. Ondowapi or Chief Tribe has the full right (Veto) to decide ancustomary decision. Leadership ondowapi or chief of the tribe is selected based on the offspring of the eldest son in the largest tribe that forms the customary village. For example the Tabi Mamta Customary Law of the tribe in the village of Kriku and Skrofo. The customary structure of this village begins with the highest stratum is the Head of the Tribe and then oversees the clan leaders (keret). The tribal chief holds the highest authority, followed by the clan chiefs.

\section{Social and Cultural Aspects of Tabi Mamta Indigenous Peoples In Amdal Process}

Development in Papua Province when not yet involve all indigenous and tribal peoples. Indigenous and tribal peoples involved in development are intended to provide consideration in accordance with local wisdom applicable in the area. But in reality the current society is not involved and only as a spectator especially in Papua. In addition, development in Papua is currently aimed only at infrastructure development but not human development. So there is no change in the mental attitude 
of the Papuans. This is evident with the consumptive lifestyle of Papuans. Especially with the policy of providing assistance to the villages, do not give an impact on the mental development of Papuans.

There was the sale of customary lands, while the value of land for the Tabi Mamta Indigenous People was sacred. Customary land rights and powers are an integral part of customary structure, so that when customary lands are sold, there is a fundamental change to the authority and power of the Tabi Mamta Customary Law Community.

\section{The Indigenous Peoples Stratification}

The customary structure of indigenous people's life in Tabi Mamta is seen in the customary stratification that still exists today. The stratification has been customary and structured by the ancestors of indigenous peoples. The form of social stratification in Tabi Mamta indigenous people is known by the customary stratification of Ondofolo as well as in the section of Tabi Mamta custom territory called Iram system. The indigenous structures formed in customary stratification have been established since ancestors.

Ondoafi or Iram is the highest level in traditional structures in Tabi Mamta customary territory. For example in the Sentani customary area there are 33 Ondoafi that protect tribes and clans, while in other parts there are several Iram and collective leadership systems (tribal chief). Relation to development especially in the field of Amdal, the stratification of customary is currently not running in accordance with its function. This is because indigenous peoples are not involved and given the authority according to customary stratification in the development process in Amdal field. There should be a strengthening of indigenous peoples at the village level by the government, by providing assistance to customary components in traditional stratification, as well as providing opportunities for customary leaders such as Ondoafi, Iram or Chief to play a role according to their functions, including in the Amdal decisionmaking process.

The mechanism of development planning including environmental planning is through the EIA process has been running until now, but the implementation is not maximized considering the government's intervention is still high, by not giving full authority to the Indigenous People to regulate themselves in the development planner in the field of environment. Indigenous and tribal peoples have been able to plan the development of the environment from generation to generation. Customary planning mechanisms have been established before the government exists.

For example in environmental planning, especially in Amdal field, the stages in the customary structure are carried out by firstly giving Ondoafi information to the entire community that there will be an activity plan of a company, then the second mechanism of Ondoafi invites the traditional chiefs and ulayat rights owners to the meeting customary discusses the intended activity plan.
The place of the customary meeting took place in Obhe. All responses and aspirations of customary chiefs and owners of customary rights will be discussed in Obhe, such as the aspiration to refuse activities because there are sacred places that the ancestors should not be touched by strangers or animals. This process is a process of collecting bottom-up indigenous peoples' aspirations carried out by Tabi Mamta indigenous peoples. This mechanism does not work. This is due to the role of the customary Mechanism has been replaced by the role of Musrembang which is more normative and guided by village officials.

In addition, the mechanism of crafting the development aspirations from the lower levels is not working because the Musrembang apparatus, which is a medium to mediate this process, does not understand customary knowledge, traditional rules and local culture. Therefore the government should strengthen the indigenous peoples by providing a portion of authority to ondoafi and supporting customs with funds and facilities. Ondoafi and Iram and tribal chiefs hold the highest authority in safeguarding and exploiting customary symbols in the form of customary lands, forests, waters and others contained within the customary territory. Utilization of custom symbols begins with talks with ondoafi, because ondoafi is the representative of the people as well as leaders and leaders.

For example, in Nimbugresi District of Jayapura there is a Levite tribe in which there is a Wou clan who was appointed osebagai ondoafi by the clans of Sanuel, Klemen, Traper, Mebri, Mes, Nian, Tegai, Srom, Rumei and Tabisu. The decision-making process in the customary stratification begins with the customary. All clans gathered to agree on the problems faced by the customary party. Furthermore, from the agreement and the consent of the community is endorsed by ondoafi as a decision. As in Kampung Yetti and Kriko there are Manam tribes. Manam tribe appointed Ondoafi Manam which is customary structure is recognized as the elder of the five villages namely Yetti Village, Wembi Village, Kampung Atibai, Kampung Ujung Karang and Kampung Skuare.

In these five villages there are several clans of the clan Tungkir, Marga Less, Marga Bewangkir and Marga Sakor. In the customary territory of Tabi Mamta Manam Tribe there is Manama Customary Council (DAM). The duties and functions of the Manama Tribal Council (DAM) are to deal with issues of violations that occur within the community.

Beginning with customary land use issues for development purposes up to issues of promises of unapplied companies to indigenous peoples Tabi Mamta Suku Manam. Tabi Mamta Customary Law Community, especially Manam tribe in the village of Kriko wants if there is a problem between the company and society customary law then the settlement is done together.

Starting from the process of meeting up to the decision-making process. Customary parties want a joint meeting to avoid arising suspicion or distrust of indigenous peoples against the company. In addition, the customary community does not feel disadvantaged by the decisions issued by the company. Indigenous people 
want openness among various parties. Coordination among the troubled parties continues to be undertaken by customary parties, companies and governments. Continuous coordination will provide customary benefits, such as solving non-discontinuous problems. Indigenous peoples do not want any unilateral or unilateral settlement

In addition, in solving the problem must be attended by parties who really have the right to take decisions and can not be represented. Indigenous peoples have a habit in customary meetings that all thoughts put forth in the meeting will be a fixed and immediate decision to be implemented. Indigenous and tribal peoples do not want a mechanism of stewardship of issues that do not take sides with honesty and balance. Indigenous Peoples Tabi Mamta Manam tribe in solving problems using the principle of honesty and balance in indigenous peoples.

The party is responsible for all the decisions made, because the decision also represents the spirit of their ancestors. For that the Indigenous People of Tabi Mamta Manam Tribe does not want the customs problems resolved by companies and government. Governments and corporations can only provide material impulses to indigenous and tribal peoples, but do not interfere to the affairs of decision making. By carrying out such a function, then indigenous peoples themselves feel that they have been recognized by the government and the company.

The existence to manage their own natural resources and create their own welfare. The Indigenous Peopleof Tabi Mamta Tribe Manam believes that programs produced by the government and companies will be accepted if the programs benefit the indigenous people. Despite the views of indigenous peoples, it is beneficial but if it can not be realized the Indigenous Peopleof Tabi Mamta of Manam tribe will not accept the program and potentially create conflict among indigenous people of Tabi Mamta tribe of Manam tribe with company or government, Tabi Mamta customary law Manam in decision-making is not based solely by individuals, but decisions collectively among indigenous and tribal peoples themselves.

The collective decision will then be voiced by Ondoafi or Chief Tribe. Chiefs are very active role in the life of indigenous people of Manam tribe. Before voicing the results of indigenous peoples' decisions, the chieftains coordinate with ondoafi and clan heads. Communication between heads of tribes, ondoafi and clan heads (keret) is done continuously. This communication is not interrupted, if interrupted it will lead to conflicts within indigenous peoples.

In addition, conflicts can also occur if the company or government to communicate continuously to certain people by excluding indigenous peoples Tabi Mamta Tribe Manam collectively. Government or companies need to know the custom structures that exist in the life of indigenous peoples Tabi Mamta Manam tribe.

For example in the tribe of Manam there are clans (rail). For example, in Suskun village there are Marga Bogofier, Konondoi clan, Giryar clan, Mesas clan, number clan, Abar clan, Krunggir clan and Kumryagir clan. While in the village there is Marga Kera, Putui, Itungkir, Nyumbori, while in the village of Kriku there Menarga Marga and Marga Bewangkir. These clans recognize the principle of decision-making that is the birthright of a son (Patrenial).

Also in decision-making is not only based on the decision of the Tribe Manam, but they will communicate with other tribes around them like the tribe Ewir. In Senggi region there are several tribes, including Knap Tribe, Mela Tribe, Nanai Tribe, Woi Tribe, Mangu Tribe, and Tribe Wetlai. In this region the chief of the tribe oversees the Chairs of Keret.

The decision-making process on indigenous land use begins with the customary village (Fin) meeting, with the approval of the community and clan leaders (keret) of the customary land owners. In Kwansuvillage there are 5 (five) tribes of Waru, Bemai, Yaram, Bano, and Kwano. Each has a tribal chief and ondoafi.Dalam traditional stratification Tribal heads play an active role to control the life of his tribe, while ondoafi role validate and protect the results of existing decisions.

On the other hand ondoafi can not make its own decisions. If ondoafi takes his own decision then the consequences will be death. The stratification of is also seen in the life of the Balli tribe who inhabited the Nimboran area. The clans in the Balli tribe are Demonggrang, Demotekai and Yaung. The customary structure is seen with the selection of the Balli genus as Iram which is determined by descent. All decisions are taken jointly by the existing clan.

Iram's function is to give seriousness or confidence to all existing decisions. The decision-making process begins by listening to the aspirations of the clans within the Iram. The task of unifying the clan aspirations is the task of a Tekai. Task Tekai as well as advisor will be assisted Duneskingwou as spokesman. Furthermore, in the event -meeting as a regulator of the event conducted by a clan Rum status. After all the decision of the meeting is produced, Iram can not directly issue the decree statement, but must hear from the clan with status Bemai who is in charge of carefully assessing all decisions that will be issued by Iram.

In this region, each tribe has a different Iram. If there is one decision in one Iram, the other Iram can not interfere with Iram's customary business. However, if the decision concerns the territory under Iram's other authority, coordination will be made between Iram before making a decision. The clues about the clan that became Iram in a region were conducted using a patristial hereditary approach.

In Beniekvillage there are Sawa tribes. The Sawa tribe was led by the chief. Chiefs have played an important role since their ancestors existed. The concept of ondoafi had just been accepted by this tribe in the Dutch era. Thus with the influence of the outside of the customary structure began to include ondoafi in the custom stratification in this tribe. In addition there is a tribe in Gerusa Village Jack. In this ethnic life the role of ondoafi is very dominant in decision making.

Decision making is done following the starlification of the cohesion. Ondoafi will consult with the chiefs and clan heads before making a decision. In 
addition there is a stratification in Village Santosa where there is a general ondoafi and ondoafi clan. The decision-making process takes place within the customary meeting, involving the clans (keret) within the tribe.

The role of the general odoafi is very active in the decision-making process. In Tarvi village there are 5 (five) tribes namely Ondi (Taudufu), Bernepu, Kaisiu, Fetowin and Taurui. Indigenous stratification shows that in the village of Tarvi the role of ondoafi is very active. Ondoafi will consult with the customary land owner before making a decision. Ondoafi has more power to make decisions because people believe that a direct, inner connection occurs between ondoafi and the spirits of the ancestors.

For example when someone breaks a ban ondoafi to go somewhere, and if violated it will appear storms at sea and on land, even though it was still the shady season. In Sawesuma village there are 4 (four) tribes of Tekbo, Digan, Tribe Jasa and Tribe Bungu. Each tribe has a tribal chief, and above the tribal chief there are ondoafi who play an active role in indigenous peoples. The decision-making process is in the hands of ondoafi after asking for consideration from each tribal chief.

\section{Permissive}

Permissive attitude is an open attitude in giving permission to the utilization of natural resources. Development to be held in the territory of Tabi Mamta Indigenous Peopleis required to obtain permission from customary parties. The development plan to be held in Tabi Mamta's customary territory of Ondoafi's leadership system is done in advance through notification to the local government.

Furthermore, the government convey the purpose of development to ondoafi, and ondoafi will convey to the tribes and clans that have ulayat right on land yuang will be used as media of development.

In indigenous communities Tabi Mamta the process of licensing of the party starts from the talks conducted by families in a clan or called a rail. After the clans or clans in a family speak for themselves in their extended family and a decision is obtained, then the result of the decision is brought by the chief to be discussed in the. Indigenous peoples will gather in the (Obhe) to discuss the purpose of the development plan.

Ondoafi will invite heads of tribes and trolleys to attend and provide advice, feedback and opinions. Suggestions, inputs and opinions are given by first considering the customs and culture of the local community. While in the Iram system, the decisionmaking arrangement is carried out through a custom process involving the house's eyes (family in one clan), tribal chiefs, and clans appointed as spokespersons (Duneskingwou), advisors (Takai), organizers (Rum) As well as the decision maker (Bemai). Such a decisionmaking process is called "The Process of Sincerity".

In Benyom village there are Kekri (Yantewo), Tecuari Tribe, Bano Tribe and Kasmando Tribe. Each tribe has Iram and other devices respectively. The licensing process begun with the holding of the meeting at the family or clan level then continued to the village level attended by indigenous peoples and Iram devices in each tribe. The highest decision is at customary meeting in village. Furthermore, one of the Tabi Mamta custom territory Mix System between ondoafi and chiefs of tribal power occurs in the tribal region of Manam.

In this region there are companies that operate. The company when entering in the territory of the Manam tribe did not approach the chief or ondoafi residing in the village. Approach done by the company through local government. The Tabi Mamta Customary Law Society of Manam felt that the presence of the company had bypassed the customary authority of the region.

There are 2 (two) conditions of permissive attitude shown by indigenous people in Amdal process. First, when indigenous and tribal peoples no longer have bargaining power over their natural resources. Indigenous and tribal peoples will be permissive of investors' requests to exploit natural resources because previously investors have licenses from the government. As a result of not having the bargaining position, the Indigenous People is resigned in giving permission openly. Second, when indigenous and tribal peoples feel fully involved in making decisions at the level.

The result of the decision to grant permission will be shown openly through the mechanisms occurring within the customary structure. The permissive attitude often encountered within the Tabi Mamta Indigenous Peopleis the first permissive attitude, where indigenous and tribal peoples are willingly and openly allowing investors to exploit their customary symbols because investors have received prior permission from the government.

This situation will lead to conflicts in the future among indigenous peoples, among indigenous and tribal peoples with the government and investors. Therefore, before the customary community gives permission to use customary land, it needs to be mediated by the government. So far, the mediation established by the government through Musyawarah Pembangunan (Musrenbang) at the village level does not take into consideration the results of decisions made by indigenous and tribal peoples in the (Obhe). Development Deliberation (Musrembang) in villages is only normative, oriented towards securing government programs.

Thus the needs of indigenous peoples from the cultural side are often not accommodated. For example the need to preserve sacred customary lands, the need to invest, the need to become masters on their own land, are the things that are often ignored by the government. The government is more oriented towards material development, infrastructure than development of cultural aspects of Tabi Mamta indigenous people. Tabi Mamta Indigenous People has a habit since hereditary in giving permission of customary land use starting from para-para adat (Obhe).

Para-para adat (Obhe) is a place where people give suggestions, opinions and responses to development plans that will be held in Tabi Mamta customary territory. Suggestions, opinions and responses include 
permitting, rejecting development, until making any decision on behalf of indigenous and tribal peoples.

\section{Continuity of Communication}

Tabi Mamta Indigenous People is a Indigenous People that is open in terms of communicating with outsiders. The Tabi Mamta Indigenous Peopleholds 2 (two) principles, namely the principle of balance and the principle of relationship when meeting with outsiders who will utilize Natural Resources owned by customary law community.

The outsiders are migrants from outside the customary law of Tabi Mamta. The principle of equilibrium in Tabi Mamta's Indigenous People implies that unbalanced use of natural resources will bring disaster to Tabi Mamta's customary law community, whereas the relation is meant to be the brotherly relationship between the Tabi Mamta law community and the outsider is not a momentary relationship when one The parties have felt benefited then left the customary party.

For that Communication between the Indigenous Peopleof Tabi Mamta with the immigrants done continuously, believes in the sense that there is a learning process on the customary side and seriousness. If these principles are not exercised by outsiders, what will happen in Tabi Mamta's Indigenous Peopleis suspicion and mistrust of outsiders.

The migrants enter the Tabi Mamta customary territory in groups such as transmigrants from Java, Bali Island and Nusa Tenggara Island. In addition there are also migrants imported by the company such as PT. Rimba Matoa Lestari, PT. Tandan Sawita Papua engaged in Oil Palm, PT. Semarak Timber is swarming in the field of Forestry, PT. Berlin Krida Jaya engaged in the processing of Sago cultivation.

Some companies enter the Tabi Mamta customary law area through licensing from both the District and City governments. Communication between companies and customary law communities Tabi Mamta has little intensity and continuity, when compared to the intensity and continuity between the company and Provincial, District and City Governments. This is evidenced by the loss of information on the presence of companies in the territory of customary law of Tabi Mamta.

The Tabi Mamta Customary Law Society did not get any information about the presence of the company in the customary law of the Tabi Mamta community. For example, the Tabi Mamta Indigenous People of the Manam tribe, who wishes that everything related to the problems between companies and indigenous peoples should be continuously communicated. If the communication is interrupted it will potentially conflict.

One form of conflict that occurs is the result of the company's decision which then led to indigenous people's discontent. This dissatisfaction will then lead to adversity leading to anarchist destructive activities. In addition, the form of communication that is expected by the Indigenous People of Tabi Mamta Manam tribe in the form of a proportional communication. This communication will occur if the company contacts people based on existing custom structures.

For that the company or government must understand the people who are in the customary structure and have the authority to voice the voice of indigenous peoples. Such communication will result in decisions or agreements that can solve problems among the troubled parties. Misinformation in communication between indigenous peoples and companies or governments is usually due to some information that does not reach the parties in communication.

For that the initial process of communication must be maintained sustainability. All information to be communicated is acceptable to all parties. For example, often the Indigenous People of Tabi Mamta Manam tribe does not know with whom to communicate, who is authorized to make decisions in the organizational structure of the company.

So often when the Indigenous People of Tabi Mamta Manam tribe invites the Company and Government present together to discuss the problem, the presence is only represented by people in the company that can not take decisions at that time. At the end of the meeting there will be dissatisfaction with the resulting decisions. To avoid a sense of suspicion and a high sense of respect for the Indigenous People Tabi Mamta Manam tribe, then the implementation of communication is not implemented in large hotels

The Costumary Law Community Tabi Mamta Manam tribe feel highly respected existence when the communication is done in the village customs. The kampong is a place considered sacred by the indigenous people of Manam tribe because of that place their ancestors until the present generation held a meeting to discuss the existing customary issues. Often in the Amdal process there is an unsustainable communication between the Tabi Mamta Indigenous Peopleand the investor who will manage customary symbols belonging to the customary law community. Unsustainable communication will have an impact on the distrust of the Tabi Mamta Indigenous People against other investors who will enter to utilize custom symbols in the Tabi Mamta customary territory.

\section{Reciprocity}

The concept of repayment (reciprocity) does not apply in the life of the Tabi Mamta Customary Law Community. The concept of repayment in the form of assistance from the company is opposed by the Tabi Mamta Customary Law Community. The provision of assistance made by the company that will invest in the Tabi Mamta Customary Law Area is the company's effort to master the customary rights of the Community.

In the Amdal Process in the Tabi Mamta region, the concept of repayment will only bring suspicion among indigenous and tribal peoples, especially in the clans of ulayat owners. The suspicion of fellow clans 
will bring conflict in the Tabi Mamta customary law community. The customary rights to land, water and all the plants and animals that live therein are hereditary rights that can not be bought or replaced in the form of compensation or material assistance.

The right is not a sole right but a right of communal or customary right inherited from generation to generation. In the ulayat right there is order which has been regularly inherited by the ancestors. The order has a Magical-Religius value especially related to the values of life's morality. For example, humans have a strong relationship with the land due to human reasons derived from the soil.

There is also a view that the clan in certain tribes derived from the names of plants and animals. In addition there is also the view of the Indigenous People about the importance of respecting the lake (the story of the occurrence of Lake Sentani), rivers and springs (story of the occurrence of rivers coming from the Cycloops mountains). Therefore the Tabi Mamta Indigenous Peopleconsiders that the compensation system or material aid as compensation for the use of the right to land, water and plants and animals which is above it, is a capitalist system.

Tabi Mamta Indigenous People from generation to generation does not recognize the system of repayment with migrants, foreigners and communities outside the Tabi Mamta Customary Law Community. The reciprocity system applies only between families and clans in the Tabi Mamta customary law. This is evidenced by the existence of repayment system in the ceremony of marriage, grief ceremony, and traditional ceremonies associated with the ritual of honor to the ancestors. Tabi Mamta Indigenous People viewed reciprocity among society with company or better known as compensation rights ulayat really not known in life of custom law community Tabi Mamta.

Usually the compensation made by an outsider begins with a tap door compensation. The act of compensation is an economic act that is very much against the customs and customs of the people. Such as tap door compensation, road and bridge compensation, scholarship compensation, traditional market compensation, village development compensation are all since the ancestors were not known in the Tabi Mamta customary law community. Indigenous and tribal peoples in meeting their economic needs are carried out with a local cultural approach. Such as the exchange of livestock products with the results of the garden in meeting the needs of the wedding ceremony, grief and other ritual ceremonies. All this is done to maintain the principle of balance and principle of relations within the Tabi Mamta customary law community.

The Indigenous People of Tabi Mamta holds that the compensation given by outsiders to indigenous and tribal peoples is a form of outsourced tribute to the ancestors and customs of Tabi Mamta customary law community. However, what happens today is compensation is a substitute for customary lands. When the compensation took place for the Tabi Mamta Indigenous People was the beginning of the loss of rights to the lands given by their ancestors. Companies present in Tabi Mamta customary areas often approach with indigenous and tribal peoples by delivering promises to the community As an example that occurs in the territory of Tabi Mamta Manama Tribe.

The company promises clean water network, customs like customary children, house building, every clan gets the help of four-wheeled vehicles, and livestock assistance. All company's promises are submitted to the Indigenous People of Manam Tabi Mamta. These promises if not fulfilled will potentially lead to a sense of distrust and conflicts that prolonged. Therefore, in response to the promises demanded by indigenous and tribal peoples, in a meeting between the company and the Indigenous People of Tabi Mamta of the Manam tribe, the meeting must be attended by the chairman of the company who can take the decision at the time.

Thus indigenous peoples feel highly appreciated, the level of trust of indigenous peoples can be maintained, and the level of suspicion will decline further. In Beniek village there are Sawa tribes. In this region often occurs communication between Sawa tribe with existing companies. Assistance from companies is often given to the Sawa. Suku Sawa do not recognize the process of buying and selling land, which there is to provide land for use by companies, not to own. Often the company promises promises that attract the attention of the Customary Law Community. The promises are intended to enable the company to have customary land for investment purposes.

For example, in the village of Gerusa the company promises to the Terss, Manoa, Jasa, Jack, Yess, Digam and Tetbo tribes, to be given 4 (four) hectares (Ha) of land to be owned by every household head. The fields will be equipped with certificates. In Santosa village there are Targualam, Yandu, Sasbe, Meigar, Kabri, Worto, Wakan and Tuku Owe. These tribes agreed before the exploitation of indigenous lands were required to do "gifts of door money" to those tribes.

In Sawesuma village there are also company promises of honorariums to be given to ondoafi, educational scholarships for village children. These promises are given by the company to the ondoafi with the aim that customary lands can be utilized by the company.

\section{History of the Past}

The history of the past about the failure of relations among firms investing in the territory of Indigenous Peoples had an impact on the existence of the Tabi Mamta Customary Law Community. The failure of this relationship greatly affects mental, character, competitiveness even psychology of society. In the Amdal Process there are promises set forth in the Amdal document as a form of community development program from the company to indigenous and tribal peoples. These promises are often incompatible with the needs of the Tabi Mamta customary law community.

Tabi Mamta Indigenous People has a life philosophy Promise to keep, and Promise to be executed. 
Past failures between the company and the Tabi Mamta Customary Law have the potential to cultivate suspicion, distrust, pretense, and communication gaps. Forms of past historical failures include companies only communicating with the government, many companies making promises to the public, using the apparatus (militarism) to intimidate some societies that do not support the presence of companies in the Tabi Mamta customary law.

This is felt by the Indigenous People Tabi Mamta Tribe Manam where the promise to complete the Ropes of Love has not been implemented by the company. Ropes of Love which will be completed gradually for 4 (four) Years with the value of each location of $10 \mathrm{Ha}$ will be given compensation of 20 Million. This decision comes from the company itself not from indigenous peoples. Company promises that are often delivered and unsigned will increase indigenous peoples' distrust of the company.

In addition, the vagueness of the party responsible for the promise is often experienced by the indigenous peoples of Manam Tribe. The unclear responsibilities were strongly influenced by the political and economic situation that existed at the time. For example, the company's promises as outlined in 9 (nine) forms are not through the process that has been practiced by indigenous peoples since their ancestors existed to this day. In this case indigenous peoples are involved when it is required by governments and companies to form cooperatives.

\section{Culture value}

The Tabi Mamta Indigenous Peoplehas cultural values that have been maintained to this day. Cultural values embedded in the life of the Tabi Mamta Indigenous People are manifested in respect for the existence of customary land, protection of forests with everything living in them, the rivers of the sea and the coast. These values provide prosperity and comfort in the life of the Tabi Mamta Customary Law Community. The cultural values of the Tabi Mamta Indigenous People are filters of new cultural values (diffusion, assimilation and acculturation) in the life of the Tabi Mamta Customary Law community.

Indigenous peoples of Tabi Mamta are strengthening their cultural values through strengthening institutional relationships, either in customary (Obhe) customary meetings, as well as family gatherings in clans (tribes) of each tribe.

One of the cultural values within the Tabi Mamta Indigenous Peopleis the Land Value of Indigenous People. Tabi Mamta Indigenous People does not recognize the system of buying and selling custom land. Customary land is an integral part of the customary structure of Tabi Mamta Customary Law Community. So when customary lands are sold then there will be a change of power and authority within the customary structure. In the EIA process in the Tabi Mamta customary area, there are often violations of cultural values of indigenous and tribal peoples. The cultural values of indigenous and tribal peoples are the value of land.

Often companies assess low land by trying to calculate the economy against the value of land. Potential conflicts arise when investors make land compensation based on investor size. On the one hand, indigenous and tribal peoples are not given the opportunity to give value to the land in the EIA process based on the view of the Tabi Mamta customary law community.

For example the Value of Land in the Indigenous Demutru region. Tabi Mamta Indigenous People in Demutru customary area believe that Land is Mama or Mother or in Nambloung language called Me. According to the teachings of (Woi Iram), the land should be kept, protected and not trafficked to foreigners. Whoever sells $\mathrm{Me}$, to a stranger then he will be burned with the heat of the sun, and his body will be eaten by worms and result in prolonged civil war.

The decision-making authority over Tanah is on Ondoafi, after receiving various inputs from the clans of each tribe within the village. Ondofolo has supra natural power, because ondofolo is considered by the Tabi Mamta Indigenous People as the incarnation of god. The introduction of new values in the form of the entry of religion, science and technology into the cultural values of the Tabi Mamta customary law cause the weakness of power and authority of ondofolo. Customary order will shift, and experience the decline of values when it is brought into the political and economic aspects. Even not only the decline of values, but will lead to poverty.

The Costumary needs to be restored to pure, simple values, and uphold customs and appreciate customary leadership. Indigenous values that are still embedded in people's lives are maintained and preserved. Such values are the religious values of a place (shrine), animals, trees, water sources. These values still exist and are maintained by the Tabi Mamta customary law community.

Evidence of customary values in environmental management (Environmental Wisdom), among others, restrict the collection of certain types of trees, the collection of water at certain water sources that are only allowed for Ondoafi, Iram or Chief Tribe, hunting animals such as Bird Cenderawasih Which is considered a bird that comes from a god. Therefore, violations of customary values are the responsibility of the government. The command is responsible because the government as the ruler has a development policy that is not owned by the Tabi Mamta customary law community. Therefore, the Government is responsible for shifting customary values.

One form of government responsibility is to recognize and restore the role of customary existence in the customary order as the owner of natural resources. The government conducts guidance, empowerment and strengthening of the customary. Efforts to restore customary values and customs need to be sustainable. Customary values will be a force for development. Traditional values existed before the Government and Religion. 
As an example before the existence of religious values entered into the customary order, then the values of trust have existed before. For example, the Metu Debi Declaration contains custom values that are understood as a philosophy of "We Can Hold The Wheel, But Can Not Determine The Direction of Wind and Current".

The Tabi Mamta Indigenous People still holds the basic principle of sovereignty over custom symbols in the form of Natural Resources and everything contained within it. The values of beliefs are closely related to customary symbols. Utilization of symbols will greatly affect the life order of indigenous peoples. For example, the conflict between companies and indigenous peoples is due to the utilization that is done in places that are considered sacred by indigenous peoples. In addition, in the customary order there are values of mutual cooperation. The value of gotong royong can be seen in the loyalty of indigenous peoples to traditional leaders in indigenous villages. These values need to be reappointed by the government and investors.

With the inclusion of new cultural values into the life of the Tabi-Mata customary law community, there is a change of attitude and behavior of people in their lives. The inclusion of village governance systems, Agrarian Law, Forestry Law, information-technology, communications and migrants brought in by the government and companies have brought significant changes in the life of the Tabi Mamta customary law community.

Changed values such as the loss of customary stratification of a centralized village government on one leader (Ondoafi, Iram or Tribal Chief) are displaced by the dualism of leadership, the headman and village head, the displacement of the ulayat rights or the right of collectiveness to the land to individual ownership The existence of Agrarian law, the displacement of cultural utilization zone by Tabi Mamta Indigenous People such as sacred forest and forest that can be utilized is changed by the area of cultivation and protected area regulated by the forestry law. The government has not yet screened new cultural values that affect the cultural values of the Tabi Mamta customary law community. The community has not felt the strengthening of the government's base.

The strengthening of the base needed by the Tabi Mamta Indigenous People is strengthening the knowledge of the Tabi Mamta Indigenous Peoplethrough formal and informal education level, besides that the community wishes to strengthen the values of the land, strengthening the change of cultural acculturation.

\section{Norms and Customary Sanctions}

The Tabi Mamta Indigenous People still maintains customary norms in its life. The customary norms that are still maintained among others relate to customary land ownership. Form of customary norms that still apply the rules of use ulayat land rights land, rivers, lakes, coastal and sea. The ownership of customary rights applies only to the clans, rags and tribes belonging to the structure.
In the Amdal process it often does not accommodate all customary norms prevailing in the Tabi Mamta customary area where investors will manage the symbols of custom symbols. One example of customary norms still prevailing in the life of the Tabi Mamta Indigenous Peopleis currently in the Demutru customary territory. The customary norms relating to the management of territories and natural resources are listed in the Waidemuo Law (the Dematru Customary Law) in Articles 4 and 5 stating "Do not take the goods of others without the permission of the concerned persons and do not rob people of other lands or gardens or families other".

Customary norms or customary rules prevailing in the Indigenous Demutru region consist of the Laws of Waidemuo, Demutru and Mako. Waidemo's Law consists of 6 (six) articles. Article 1 reads; Fear and honor Wai Iram; Article 2, Fear and respect for parents; Article 3, Do not covet the wives of other persons or women; Article 4, Do not take the goods of others without the consent of the person concerned; Article 5, Do not rob land and Article 6, Do not kill anyone else if it is not for violating Waidemuo's Law and other customary laws called Demutru.

Furthermore, Demutru Law consists of 15 articles. Article 1 reads; When people are anywhere in the world, Wai-Iram always sees and cares for all his behavior and deeds; Article 2, Grays or elders are the representatives of Wai Iram in this world; Article 3, It may see a woman's tuning or feet but is not allowed to see and notice the upper thigh calves of a woman because it is not good; Article 4, It is possible to kill another person if he uses his wife or seizes the land of a family's right; Article 5, Must not undermine Iram's authority because it can be killed; Article 6, People who are many mistakes and do no good, if they do not want to repent will be attacked by disease; Article 7 Each boy, starting at the age of twelve or less, must enter the dormitory at the initiation house (Injo Yamo), which is nurtured by the government (in this case Iram, Bemai and Tekai as learners). For adolescent males who do not go to education can be killed by the Spirit or the Magical Creatures (Injo);

As for the things taught in the initiation house (Injo Yamo) in the form of fighting skills, hunting, gathering, farming, planting and other skills related to survival. Article 8 , Women are educated by mother and father at home until adulthood; Article 9, carving and songs belonging to one family (Tang) should not be followed by another family (Tang); Article 10, War only occurred on the announcement of Iram who gave the mandate to Plo Iram (Commander of War); Article 11, All men shall be educated as members of the armed forces; Article 12 Education is nurtured by a container by the name of Injo, and those who run Injo are called Injo-Hlu; Article 13, the crystal bracelet (Hamong) is held and stored by Iram.

Bracelet has the highest value and the most expensive; Article 14, Everyone is not allowed to organize a major dance party event (Kebi) on a large scale because it is Iram's right; And Article 15 states that if any person continuously violates the provisions and has committed a crime, if not repentant, although never 
punished or given advice then Duneskingwouw that is the head of Tang or clan is entitled to kill him. Other customary norms are Law Makko. Makko's Law consists of 10 Articles.

Article 1 states that every person has the right to devote to Wai-Iram; Article 2, If there is a gray or an elderly person sitting, you pass by in front of him or defend him by squatting or sitting with him; Article 3, An unmarried young man is forbidden to eat or drink and or to gather with married adults; Article 4 If a person kills another person for taking possession of his land, then the plot of land shall be left to the damaged family (this is specific to the adjacent lands); Article 5, Iram is prohibited from eating and drinking with commoners or commoners; Article 6, Iram's orders must be upheld whenever continuous resistance must be punished; Article 7, any adolescent or youth who misbehave beforehand, when entering Injo Yamo's boarding school then must be killed; Article 8, therefore the role of parents is required to foster or teach their children before entering boarding Injo Yamo; Article 9 A man may marry if he has been able to perform the usual work of an adult such as making a garden, making a house, or shooting a pig. Likewise a woman if she can already plant in the garden and others; Article 10 states that marriage must be accompanied by a dowry which is an entertainment for the discharge of a woman from the family (Tang), her family and relatives.

In addition, also found customary norms that are still valid in the Community of Law Tabi Mamta Moy tribe. Such norms are marriage laws called Kampug daray; The law of protection of women called Kampugyanggok; Forest protection law called Basyo nembut; The law of hunting is called maney nembut and law of Mutual cooperation called Krat. Further to this day, the Tabi Mamta Indigenous People does not recognize private ownership of mainland land, rivers, coastal lakes and seas. A form of violation of customary norms is the transfer of land ownership of land, rivers, lakes, coastal and sea from indigenous communities to private ownership. For example, land ownership is owned by individuals and companies.

This violation will be followed by custom sanction which is granted by the customary party in this case the owner of customary rights against the party who surrenders the customary land to the company or individual. The sanctions are in the form of alienation from the Tabi Mamta Indigenous People by excluding all customary processes that are taking place in the Tabi Mamta Customary Law Community. Tabi Mamta Indigenous People does not recognize custom sanctions in the form of compensation. This is because the compensation provided by the company or individual to the ownership of customary lands is contrary to the customary values that the land is a common property and can not be traded.

Business values can not enter in traditional values due to different color spectra. The Indigenous People of Tabi Mamta recognizes sanctions derived from ancestors and ancestral spirits, and sanctions derived from nature. The concrete form of the sanctions can not be seen but the consequences of the application of sanctions can be seen with the sacrifice of life. The stronger the belief of the Tabi Mamta Indigenous People is the higher the value of the fine or sanction given. For example, the displacement of some sacred places in the customary territory of Tabi Mamta Manama Tribe gives high customary sanction in the form of a fine of hundreds of millions to companies doing eviction.

The place is considered sacred because according to the belief of the tribe of Manam there is the place of the first human existence of their ancestors, and they assume that the spirits of their ancestors still exist today. In addition, custom sanctions are granted to companies that do not fulfill their promises to the Tribal Peoples Tabi Mamta Manuku Community. For example the completion of the Ropes where the value of the Rope of Love that should be determined by the Tribal Law Community of Tabi Mamta Manama Tribe based on customary values applicable, but the value is determined by the company. Furthermore, in the region of the Balli Tribe who know the customary structure of Iram, there are sanctions for those who violate customary rules. In the event of a violation of customary regulations, the applicable sanctions are murder.

While in the life of the Waru tribe of Kwansu village, in case of violation of, the sanction process will be handed over to the council. Furthermore, the council led by the head of the tribe will take decisions after talking with the clans that exist. In Beniek village there are Sawa tribes. This tribe does not recognize the system of buying and selling custom land. Suku Sawa never sells customary land, but allows their customary land to be used for development. Conflict often occurs when companies insist on buying customary land, especially lands that are considered sacred.

While in the region of Senggi there are customary norms that regulate the sacred places that should not be violated. In the event of a violation it will be subject to custom sanctions. Customary sanctions are death. Customary norms that exist in Santosavillage still valid with the ceremonies of marriage customs. The marriage treasures are Tomakobatu, beads and axes. Customary sanctions are given to those who violate marriage customs such as in the right and left thighs or other physical laws. While in Sawesuma village there is a traditional ceremony of marriage with marriage property in this region in the form of Bracelet, Stone ax and Masete (a kind of bone which both ends are flattened).

\section{The Customary Leadership}

The environmental feasibility decision-making process often ignores processes that should be done through mechanisms that apply to Tabi Mamta's customary law community. The focus of environmental feasibility decision-making is more focused on the mechanisms occurring within Amdal Commission Meetings. On the other hand the process of taking through customary mechanisms is neglected. The decision-making process through customary mechanisms follows the customary structures within which there is a customary stratification which is highly respected by indigenous 
and tribal peoples. All customary decision-making processes are conducted through customary consultation. Indigenous deliberations are conducted through the mechanisms (paths) of the path of the cohesion. The mechanism takes place in the customary (Obhe) with the involvement of clans, rags and tribes within the traditional structure.

Customary symbols are customary land, forest, waters and other natural resources under the power of ondoafi. Ondoafi is a leader in charge of serving indigenous and tribal peoples. In the Tarvi region, the role of ondoafi is very active. Legal issues that occur in the village must be known and the permission of ondoafi. Ondoafi is considered to have magical powers due to having a relationship with the ancestors. Ondoafi is considered to have supernatural powers that can bring death to a person. In addition, ondoafi is considered to recover people from illness through communication with the ancestors. All custom meetings or traditional ceremonies are held in the ondoafi house. Above ondoafi there is Tribal Council (DAS) which serves to coordinate the ondoafi in every village.

The Chairman of the Watershed Council is considered to be the general Ondoafi who oversees the village's ondoafi. Furthermore, the village's ondoafi oversees the tribal chiefs in the village of Tarvi, Muaib, Yogapsa, Ambora, Little Muris, Great Muris (Yokari) and Demta.

\section{Religion}

The Tabi Mamta Indigenous People is very respectful of their ancestors. Community religious life is reflected in the life of each family. Families still believe in places that are considered sacred. Belief in the existence of ancestors is felt by the Tabi Mamta customary law community. Especially when the natural resources of land, water, forest and life are disturbed by the incoming investment and change the order of the close relationship between the life of the people of Tabi Mamta customary hulum with nature and ancestral spirits. The beliefs of the people who have been to the sacred places in the Tabi Mamta customary area still exist and are planted in every generation. Problems often occur when places considered sacred are used by outsiders who do not understand the cultural background. This is often the case with the Amdal process, where the places considered sacred by indigenous and tribal peoples are neglected due to the lack of investor's understanding of the importance of sacred places.

On the other hand indigenous people believe the sacred places are considered to have high religious values. These places are considered to be the place where the first human existed, the place is considered that the ancestors still live up to the present time. These places are considered to be the place where the ancestral spirits reside, where the demons dwell even ordinary place is where the former tribal war occurred. In this place also Chief Tribe can call the spirits of ancestors who died when the tribal war occurred. In the area of Nimbugresi village there is a tribe of Levi. This tribe still holds the belief that certain places in the indigenous territory lies with ancestral spirits.

The guidance of the ancestral spirits is the existence of a very sacred old village. Anyone who enters the area if they do not get permission from ondoafi will get custom sanctions. The customary sanction of a fine is determined by custom. As a result of a fine that is not resolved, then the concerned can not speak anymore (mute). The forms of fines are Tomakobatu (Uda), and Beads (Ngoi). In the Genyem village region there is the Balli Tribe. The tribe of Balli gives the sanction of murder or the person will lose his memory forever in the event of a violation of the sacred places. The sacred places were determined by the Balli tribe based on the belief that the place used to form the crossroads and even the settling places of the ancestors. Ancestral spirits are believed to have been transformed into trees, stones, wood, and spirits. Due to the ancestral spirits dwelling in the place then the place is highly valued for generations. In this region only Iram can communicate with the ancestral spirits.

The form of communication is done by speaking directly with the ancestral spirits. The Indigenous Peopleassumes that their ancestral spirits heard when the communication took place. Communication and spiritual contact can not occur between the owner of the communal right elsewhere with the local ancestral spirits. In Kwansu village a strong relationship exists between nature and indigenous peoples. Chief or ondoafi can communicate with nature using mother language (Soil Language). The characteristics of the land language are usually seen from naming the names of places, villages, rivers or water sources, and usually those names are associated with the origin of humans in the region. Not everyone can communicate like this. The ability to communicate with nature occurs from generation to generation according to the right of inheritance (patrinial).

Inheritance is hereditary, if the head of the tribe or ondoafi not memiilki boy, then the right of inheritance fell on the younger brother and so on. In addition in the Tabi Mamta customary territory there is a village of Gerusa. In this area there are places that are considered sacred places. Sacred places are usually dintandai with the forest protected by indigenous peoples. Customary sanctions that occur when there are people who enter the region will be dipanah thigh. In the village of Tarvi there are sacred places that are determined by indigenous peoples. A place is used as a sacred temple because the place is believed to be where their ancestors rest when traveling long. For that the places are highly appreciated by the local community. In case of violation in sacred places it will be sanctioned by custom sanction of custom size. In the village of Sawesuma there are sacred places.

The sacred places are shaped hills covered with trees. Trees that have been marked with clear signs such as red paint. The sacred places are highly respected by indigenous peoples. In the event of violation of sacred places, it will be subject to physical sanctions for those who violate it. Contextual of each of the above social and cultural variables in the AMDAL process can be 
clearly seen in the description of the dynamics of environmental feasibility decision making in the EIA process that occurred in the Tabi Mamta Indigenous People in Papua Province.

\section{Conclusion}

1. Indigenous Peoples Tabi Mamta is a community of Customary Law that still has territorial custom territory, genealogically has kinship, has customary values and norms and sanctions, possesses cultural objects, and has environmental wisdom in maintaining the existence of Symbols Custom in the form of Natural Resources.

2. In the socio-cultural system of customary law communities there are components such as stratification, permissiveness, communication, reciprocity, past history, cultural values, customary norms and sanctions, religious and leadership.

3. Components in a socio-cultural system constitute a unity resulting from the interaction between individuals and groups in order to prevent the occurrence of environmental damage and disruption to the existence of environmental and natural resource functions.

4. Components in the socio-cultural system of indigenous and tribal peoples play a role in the EIA process in the Tabi Mamta customary area especially in the environmental feasibility decision making process.

5. Natural resources are considered as ancestral symbols inherited from ancestors from generation to generation.

\section{Bibliograph}

1. Afrizal. Metode Penelitian Kualitatif. Sebuah upaya mendukung penggunaan penelitian kualitatif dalam berbagai disiplin ilmu. Jakarta: Raja Grafindo Persada, (2014) [in Bahasa]

2. Alan Bond., Juan Palerm., Paul Haigh. Environmental Impact Assessment Review: 24:617641, (2004)

3. Anne N. Glucker., Peter P.J. Driessen., Arend Kolhoff, Hens A.C. Runhaar. Environmental Impact Assessment Review: 43: 104-111, (2013)

4. Badan Pusat Statistik. Papua Dalam Angka (Papua in Figures), (2015) [in Bahasa]

5. Bambang Rudito., Melia Famiola. CSR (Corporate Sosial Responsibility), Bandung: Rekayasa Sains, (2013) [in Bahasa]

6. Bambang Rudito., Melia Famiola. Sosial Mapping Metode Pemetaan Sosial Teknik Memahami Suatu Masyarakat atau Komuniti, edisi revisi, Bandung: Rekayasa Sains, (2013) [in Bahasa]
7. Bao Cun-kuana., Lu Yong-sena., Shang Jin-cheng. Environmental Impact Assessment Review; 24: 27 46, (2004)

8. Berger R. Thomas. Northern Frontiers, Northern Homeland: The Report of the Mackenzie Valley Pipeline Inquiry - Report Volume 1. Otawa. Canada, (1977)

9. Bo-sin Tang., Siu-wai Wong., Milton Chi-hong Lau. Environmental Impact Assessment Review; 28 : 57 $72,(2008)$

10. BP Tangguh LNG. Dokumen Analisis Mengenai Dampak Lingkungan (Amdal), Dokumen Final Andal lampiran 8.3.1, (2001) [in Bahasa]

11. Canter L.W. Environmental Impact Assessment. Second Edition. New York: Inc Mc Graw-Hill, (1996)

12. Chaunjit Chanchitpricha, Alan Bond. 2013. Conceptualising the effectiveness of impact assessment processes, Environmental Impact Assessment Review 43, 65-72, (2013)

13. Ciaran O'Faircheallaigh. Environmental Impact Assessment Review; 27: 319-342, (2007)

14. Ciaran O'Faircheallaigh. Environmental Impact Assessment Review: 30:19-27, (2010)

15. Death Carl. Mengelola Pembangunan yang Berkelanjutan (Kemitraan, Protes, dan Kekuasaan Di KTT Dunia), Yogyakarta; Pustaka Pelajar, (2014) [in Bahasa]

16. Dewan Suku Tepera Yewena Yosu. Profil Kampung Yepase. Tim Kerja DAS Tepera Yewena Yosu. Distrik Depapre-Refenirara Kabupaten Jayapura, (2015) [in Bahasa]

17. Dewan Suku Moy. Proposal Pengusulan Kampung Dosay. Dosay Kabupaten Jayapura, (2015) [in Bahasa]

18. Dinas Kebudayaan Provinsi Papua. Peta Suku Bangsa Di Tanah Papua, Jurusan Antropologi Universitas Cenderawasih (Uncen), Summer Institute of Linguistic (SIL), Dewan Papua (DAP) dan Badan Pusat Statistik (BPS) Provinsi Papua, (2008) [in Bahasa]

19. Dwi Narwoko J., Bagong Suyanto. Sosiologi: Teks Pengantar dan Terapan, Jakarta: Kencana Prenada Media Group, (2004) [in Bahasa]

20. Dwi Susilo K. Rachmad. Sosiologi Lingkungan dan Sumber Daya Alam Perspektif Teori dan Isu-isu Mutakhir. Yogyakarta: Ar-Ruzz Media, (2012) [in Bahasa]

21. Einar Leknes, Environmental Impact Assessment Review : 21: 309-334, (2001)

22. Endraswara Suwardi. Filsafat Ilmu. Yogyakarta: CAPS (Center for Academic Publishing Service), (2012) [in Bahasa]

23. Erari K. Phill. Tanah Kita, Hidup Kita (Hubungan Manusia dan Tanah di Irian Jaya sebagai PersoalanTeologis), Jakarta, Pustaka Sinar Harapan, (1999) [in Bahasa] 
24. French P. David., Stephen Sutton., Susie J. Hennings J O Mitchell., Nicholas J. Wareham., Simon Griffin., Wendy HArdeman., Ann Louise Kinmont. Journal of Applied Sosial Psychology: 35 (9):1824-1848, (2005)

25. Fuady Munir. Teori-teori Dalam Sosiologi Hukum. Jakarta: Kencana Prenada Media Group, (2011) [in Bahasa]

26. George Ritzer. Eksplorasi Dalam Teori Sosial Dari Metateori sampai Rasionalisasi. Yogyakarta: Pustaka Pelajar, (2013) [in Bahasa]

27. Gordon Walker. Environmental justice, impact assessment and the politics of knowledge: Theimplications of assessing the sosial distribution of environmental outcomes Environmental Impact Assessment Review: 30: 312-318, (2010)

28. Hadi P. Sudharto. Aspek Sosial AMDAL Sejarah, Teori dan Metode. Yogyakarta: Gadjah Mada University Press, (2009) [in Bahasa]

29. Hadi P. Sudharto. Resolusi Konflik Lingkungan. Semarang: Badan Penerbit Universitas Diponegoro, (2010) [in Bahasa]

30. Hadi P. Sudharto. Dimensi Lingkungan Perencanaan Pembangunan. Yogyakarta: Gadjah Mada University Press, (2012) [in Bahasa]

31. Jan. J.J.M. Wuisman. Teori dan Praktek Memperoleh kembali kenyataan supaya memperoleh masa depan. Jakarta: Yayasan Pustaka Obor Indonesia, (2013) [in Bahasa]

32. Javier Toro., Oscar Duarte., Ignacio Requena., Montserrat Zamorano. Environmental Impact Assessment Review:32:107-117, (2012)

33. Javier Toro., Ignacio Requena., Oscar Duarte., Montserrat Zamorano. Environmental Impact Assessment Review: 43: 9-20, (2013)

34. Jennifer L. Walker., Bruce Mitchell., S. Wismer, Environmental Impact Assessment Review: 20 : 513-535, (2000)

35. Jesper Persson. Environmental Impact Assessment Review: 26: 605-613, (2006)

36. John A Sinclair., Laura Sims., Harry Spaling. Environmental Impact Assessment Review: 29, (2009)

37. John scott. Teori Sosial Masalah-masalah Pokok Dalam Sosiologi. Yogyakarta: Pustaka Pelajar, (2012) [in Bahasa]

38. Juan R.Palerm. Environ Impact Assess rev; 19:201220, (1999)

39. Karl Polyani, The Great Transformation, Societies and economic systems, Boston: Beacon Press; Chapter IV, pp 43-44, (1944)

40. Lawrence W Neuman, Metode Penelitian Sosial: Pendekatan Kualitatif dan Kuantitatif. Jakarta: PT. Indeks, (2013) [in Bahasa]

41. Linda Stalker Prokopy, World Development Vol. 33, No. 11: pp. 1801-1819, (2005)
42. Mansoben Johszua Robert. 1995. Sistem Politik Tradisional Di Irian Jaya, Jakarta, Lembaga Ilmu Pengetahuan Indonesia (Indonesian Institute of Sciences), (Seri LIPI-RUL: no.5) ISBN 979-825806-1.

43. Marion Hourdequin., Peter Landres., Mark J. Hanson., David R. Craig, Environmental Impact Assessment Review; 35: 37-44, (2012)

44. Mathius Awoitauw, Pemimpin Transformatif Berbasis Kearifan Lokal. Jakarta. Indomedia Global Mandiri, (2015) [in Bahasa]

45. Nazir. Moh, Metode Penelitian. Bogor: Ghalia Indonesia, (2011) [in Bahasa]

46. Nicola Hartley., Christopher Wood., Environmental Impact Assessment Review: 25: 319-340, (2005)

47. Obaidullah Nadeem., Thomas B. Fischer., Environmental Impact Assessment Review :31: 3647, (2011)

48. Reed Isaac., Alexander C. Jeffrey, Sosiologi Kebudayaan dalam Bryan S.Tuner (ed): Teori Sosial Dari Klasik Sampai Postmodern. USA: Blackwell Publishing. Ltd. p.642-661, (2012)

49. Masyarakat Kementrian Lingkungan Hidup. Pedoman Tatacara Inventarisasi Pengakuan Keberadaan Masyarakat Hukum , Kearifan Lokal, dan Hak Masyarakat Hukum yang Terkait Dengan Perlindungan dan Pengelolaan Lingkungan Hidup, Jakarta. [in Bahasa]

50. Sairinen R, Environmental Impact Assessment Review; 30: 289-292, (2010)

51. Salim Agus, Teori dan Paradigma Penelitian Sosial (Dari Denzin Guba dan Penerapannya). Yogyakarta: PT. Tiara Wacana Yogya, (2001) [in Bahasa]

52. Salim Momtaz, Environmental Impact Assessment Review: 25: 33-45, (2005)

53. Schaefer T. Richard, Sociology. 12th ed. New York: McGraw-Hill, (2012)

54. Sidanius Jim., Pratto Felicia, Sosial Dominance; An Intergroup Theory of Sosial Hierarchy and Oppression, United Kingdom: Cambridge University Press, (1999)

55. Soemarwoto Otto, Analisis Mengenai Dampak Lingkungan. Yogyakarta: Gadjah Mada University Press, (2001) [in Bahasa]

56. Suranto Aw, Komunikasi Sosial Budaya. Yogyakarta: Graha Ilmu, (2010) [in Bahasa]

57. Thomas F. King, Environmental Impact Assessment Review: 20: 5-30, (2000)

58. Watloly Aholiab, Sosio Epistemologi Membangun Pengetahuan Berwatak Sosial. Yogyakarta: Penerbit Kanisius, (2013) [in Bahasa]

59. York Richard., Dunlop E. Riley, Sosiologi Lingkungan (Hidup) dalam George Ritzer (ed): The Wiley-Blackwell Companion Sosiologi, UK:Blackwell Publishing Ltd, John Wiley \& Sons Ltd. p. 851-879, (2013) 